\title{
Value addition with Blue Ocean Strategy Approach at SMI Cosmetics of Indonesian PT Company
}

\author{
Adriyani Oktora ${ }^{1}$, and Uly Amrina ${ }^{2}$ \\ ${ }^{1-2}$ Industrial Engineering Department \\ Faculty of Engineering, Universitas Mercu Buana \\ J1. Raya Meruya Selatan, Kembangan, Jakarta 11650 Indonesia
}

\begin{abstract}
PT. Budi Andhika Prima Ayudia is an industry engaged in cosmetics, the problem that will be discussed in this research is to increase product value with the aim of expanding market share, this problem was raised based on initial discussions with partners. The method that will be used is the blue ocean strategy approach. The blue ocean strategy has a 4-step framework consisting of eliminating, reducing, raising, and creating steps. This strategy is a business strategy that implements strate gies by controlling market share that is not contested. This strategic approach is expected to provide alternative solutions and ideas to maintain the sustainability of this industry, and the industry can gradually implement the strategies formulated by researchers.
\end{abstract}

Key Words: Strategy, Blue Ocean, SMI, Cosmetics.

\section{INTRODUCTION}

Cosmetics is one of the rapidly growing industries and occupies the second position in the 2015-2035 National Industrial Development Master Plan (Center for Public Communication, 2015), where 95\% of industry players come from Small and Medium Industries (SMI) (Ministry of Industry, 2018) [1,2]. The SMI partners in this research are PT. Budi Andhika Prima Ayudia. This SMI was founded in 1995 by Dra. Effiati Aryoko, Apt. Starting from a trading company, PD. Budi Andhika started his production in the field of natural-based cosmetics for beauty and body care, including hair, face, hands and feet. The products made, consist of natural ingredients and supporting materials (multivitamins, moisturizers, and herbal ingredients) and are produced with a Good Manufacturing Practice License (GMP). The product that is focused on research is pro natural 2000, this is the company's flagship product. The types of pro natural 2000 are shampoo, conditioner, hair tonic, hair mask, face mask, cream bath, and many more.

Along with business growth, on December 22, 2017 PD. Budi Andhika was formed into PT. Budi Andhika Prima Ayudia. Customers are spread throughout Indonesia including the islands of Java, Bali, Sumatra and Sulawesi. PT. Budi Andhika Prima Ayudia has been around for a long time, but with business developments that are increasingly widespread and fast, companies need a strategy in order to compete. One of the highlights in increasing the value of pro natural 2000 products is the form of packaging that has never changed until now. This phenomenon is the background for researchers to help design business strategies for these SMEs

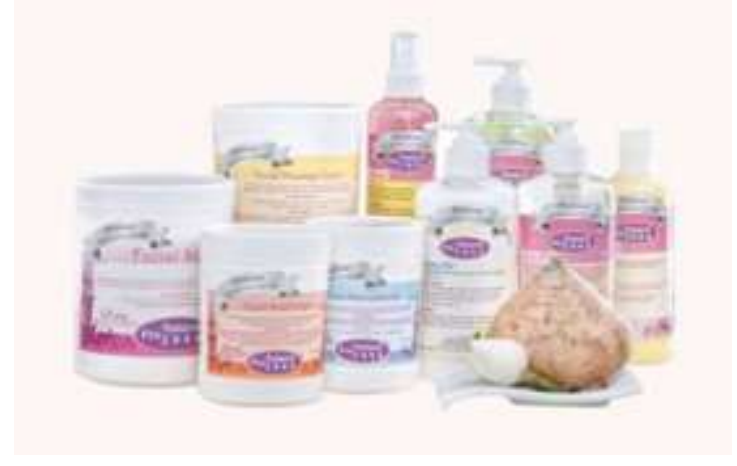

Figure 1. Product Pro Natural 2000 
Figure 1 shows that the packaging design used for pro natural 2000 products for 5 years of existence. The quality of the product must be improved so that the company is able to compete with other companies and maintain consumer confidence in the company's products. Good product quality and according to standards is very important for the sustainability of the company. Blue ocean strategy is part of the business strategy process, in terms of the definition of blue ocean strategy is a business strategy that implements control of market space that is not contested (uncontested market space), thus making competition less competitive relevant. This strategy focuses on creating added value (value innovation) from new ideas or ideas that have not been widely used, so that the company can highlight its characteristics or differentiate it from competitors and create its own market segment.

\section{LITERATURE REVIEW}

\subsection{Blue Ocean Strategy}

Blue Ocean Strategy (BOS) is a business strategy that applies the control of market space that is not contested (uncontested market space) thus making competition irrelevant (competition irrelevant). The market that is not contested is analogous to the Blue Ocean where the organization plays alone without any competitors. On the other hand, the condition of the market space is being fought over by various parties in any way as if it were bloody, so this condition is analogous to the Red Ocean or the Red Ocean [6].

The basic concept of Blue Ocean Strategy is Value Innovation, which is a way of diverting oneself from the competitive Red Ocean to the Blue Ocean which is no longer relevant (Chan and Mauborgne, 2005). Value Innovation is oriented to the entire company system that brings together the values expected by consumers and the company. In Red Ocean, industry boundaries have been accepted and the rules of competition are known. For example, companies are trying to beat competing companies in order to get a bigger market share. As the market scope narrows, the company's profit and growth prospects diminish. So the Red Ocean becomes a very tight competition. While the Blue Ocean is characterized as an unspoiled place, so it can be a place to create demand and very profitable market growth opportunities. Although Blue Ocean was created outside the existing industry, but mostly created by extending the existing boundaries. In Blue Ocean competition is irrelevant, this is because new rules will be formed [6].

To realize a blue ocean through innovation, an analytical framework is needed which is called a four-step framework, namely ERRC:

\section{Eliminate}

Companies are eliminating factors that the oceans take for granted and take for granted. Factors can be deleted because the factor no longer has value or even reduces value.

2. Reduce

Companies reduce investment in factors that do not provide increased benefits to buyers by ocean standards.

3. Raise

This step is the opposite of reduce. The company is increasing its investment in competitive factors that provide a significant increase in benefits to buyers up to industry standards.

4. Create

Companies create factors never before offered in the oceans. By creating new factors the company provides new value benefits for consumers or non-consumers so as to achieve new demands.

Strategy profile with high blue ocean potential has three complementary qualities, namely [6]:

1. Focus, the company does not spread its efforts to all the main factors in the competition.

2. Divergence, away from other players, a result of looking for and seeing alternatives and not from comparing from competitors.

3. An attractive motto, a good motto should not only be able to convey a clear message, but also advertise the offer or product honestly.

\subsection{Quantitate Strategic Planning Matrix (QSPM)}

Quantitative Strategic Planning Matrix (QSPM) is a technique to find out alternative strategies that are prioritized by the company. According to David (2009), QSPM is a tool that allows strategists to evaluate various alternative strategies objectively based on the previously identified important external and internal success factors. The QSPM method has several advantages such as the strategy can be observed sequentially or simultaneously, requires strategists to integrate relevant external and internal factors into the decision-making process, underscores important relationships that can influence strategic decisions, increases probability obtaining the final strategic decision that is best for the organization. Although it has many advantages, QSPM has the 
disadvantage of always requiring intuitive judgment and assumptions from experts. In the application of the QSPM method there are steps that must be taken, namely:

1. Identify the company's internal factors in the form of strengths and weaknesses, as well as the company's external factors in the form of opportunities and threats.

2. Create an EFE (External Factor Evaluation) Matrix and an IFE (Internal Factor Evaluation) Matrix. The results of these two matrices will be formed into an Internal External Matrix (IE) to show the company's current strategic position.

3. Enter data and weights to identify alternative strategies that are considered for implementation.

4. Calculate the Total Attractive Score (TAS) from the multiplication between the weights and the Attractive Score (AS) for each row. The result of the highest value indicates an alternative strategy that is prioritized by the company.

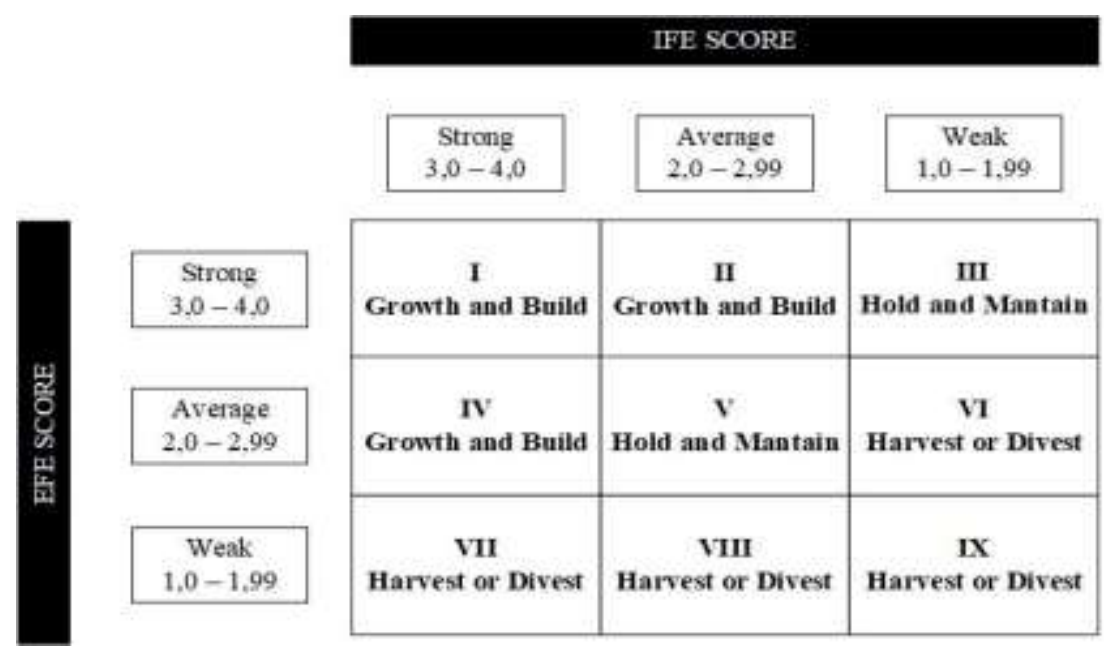

Figure 2. Internal and External Matrix

\section{RESEARCH METHODOLOGY}

Figure 3 shows that in this study, the researcher used literature and expert interviews to identify the company's internal and external factors. Identification of internal factors serves to determine the strengths and weaknesses of the company; this identification is carried out as a stage to determine the condition of the company's initial strategy canvas. Identification of external factors serves to determine the opportunities and threats that occur in the market of competitors who have similar businesses, this factor is also very important to determine the position of existence or where the company is currently located.

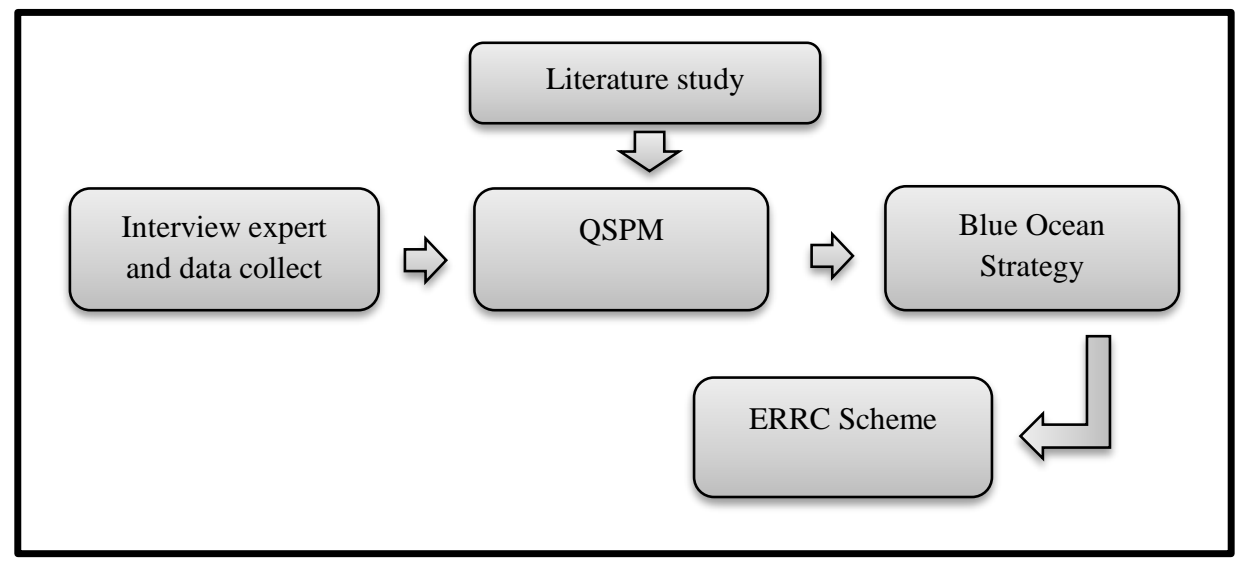

Figure 3. Research Steps Using QSPM and Blue Ocean Strategy 


\section{RESULT AND DISCUSSION}

\subsection{Internal and External Factors}

At this stage the data collection is carried out, the researcher collects the data needed to analyze the company's position in the initial conditions, which will then carry out data processing and analysis to determine the right strategy in order to survive in the competition between similar cosmetic companies. The initial stage of data collection in this research is to prepare a questionnaire, this is done to identify the company's internal and external factors. Table 1 shows internal factors of the company, Table 2 shows external factors of the company.

Table 1 Internal Factors

\begin{tabular}{clll}
\hline No. & \multicolumn{1}{c}{ Statement } & \multicolumn{1}{c}{ Indicator } & \multicolumn{1}{c}{ Source } \\
\hline 1. & Availability Human Resources & Total Manpower & $\begin{array}{l}\text { Indonesian Cosmetics Company } \\
\text { Association 2016 }\end{array}$ \\
\hline 2. & Quality of Human Resources & $\begin{array}{l}\text { Employee Performance } \\
\text { Criteria }\end{array}$ & Parlinda (2014) \\
\hline 3. & Good Cooperation between workers & $\begin{array}{l}\text { Productivity Increases, } \\
\text { minimal conflict }\end{array}$ & Davis (2014) \\
\hline 4. & Supporting work facilities & Employee Satisfaction & Assauri (2004) \\
\hline 5. & Government regulations and permits & $\begin{array}{l}\text { Completeness of legal } \\
\text { documents }\end{array}$ & $\begin{array}{l}\text { Indonesian Cosmetics Company } \\
\text { Association 2016 }\end{array}$ \\
\hline 6. & Good research facilities & Facility utilization & $\begin{array}{l}\text { Indonesian Cosmetics Company } \\
\text { Association 2016 }\end{array}$ \\
\hline 7. & $\begin{array}{l}\text { Ability to use information technology } \\
\text { (internet) in good promotion }\end{array}$ & $\begin{array}{l}\text { Number of new } \\
\text { customers }\end{array}$ & $\begin{array}{l}\text { Interview with PT. Budi Andika } \\
\text { Prima Ayudia }\end{array}$ \\
\hline 8. & Product quality and variety & Consumer satisfaction & $\begin{array}{l}\text { Interview with PT. Budi Andika } \\
\text { Prima Ayudia }\end{array}$ \\
\hline 9. & Product name and brand image & Sales figures & Tambirin (2010)
\end{tabular}

Table 2 External Factors

\begin{tabular}{clll}
\hline No. & \multicolumn{1}{c}{ Statement } & \multicolumn{1}{c}{ Indicator } & \multicolumn{1}{c}{ Source } \\
\hline 1. & $\begin{array}{l}\text { Increasing number of competitor's } \\
\text { products }\end{array}$ & $\begin{array}{l}\text { Easy to find similar } \\
\text { products }\end{array}$ & $\begin{array}{l}\text { Interview with PT. Budi Andika } \\
\text { Prima Ayudia }\end{array}$ \\
\hline 2. & Customer requirement & Consumer satisfaction & $\begin{array}{l}\text { Interview with PT. Budi Andika } \\
\text { Prima Ayudia }\end{array}$ \\
\hline 3. & Increase in similar imported products & $\begin{array}{l}\text { Consumers switch to } \\
\text { imported products }\end{array}$ & $\begin{array}{l}\text { Indonesian Cosmetics Company } \\
\text { Association 2016 }\end{array}$ \\
\hline 4. & Broad market segmentation & Varied consumers & $\begin{array}{l}\text { Indonesian Cosmetics Company } \\
\text { Association 2016 }\end{array}$ \\
\hline 5. & There is a retail market & Number of retailers & $\begin{array}{l}\text { Indonesian Cosmetics Company } \\
\text { Association 2016 }\end{array}$ \\
\hline 6. & Positive market reaction & Sales figures & Jogiyanto (2008) \\
\hline
\end{tabular}

\subsection{QSPM}

The QSPM analysis contains an analysis of the company's internal environment in the form of strengths and weaknesses, as well as the company's external environment in the form of opportunities and threats. The following is an analysis of the Company's internal and external environment. 
Table 3 QSPM Matrix Result

\begin{tabular}{|c|c|c|c|c|c|c|c|c|c|}
\hline \multirow[t]{2}{*}{ Key Factor } & \multirow[t]{2}{*}{ Weight } & \multicolumn{2}{|c|}{$\begin{array}{l}\text { Alternative } 1 \text { - } \\
\text { Strengthening } \\
\text { product and } \\
\text { company brand } \\
\text { image }\end{array}$} & \multicolumn{2}{|c|}{$\begin{array}{c}\text { Alternative } 2 \text { - } \\
\text { Utilizing information } \\
\text { technology (internet) } \\
\text { for marketing }\end{array}$} & \multicolumn{2}{|c|}{$\begin{array}{l}\text { Alternative } 3 \text { - } \\
\text { Create new } \\
\text { product } \\
\text { variations }\end{array}$} & \multicolumn{2}{|c|}{$\begin{array}{l}\text { Alternative } 4 \text { - } \\
\text { Improve work } \\
\text { facilities }\end{array}$} \\
\hline & & AS & TAS & AS & TAS & AS & TAS & AS & TAS \\
\hline Internal Factor & & & & & & & & & \\
\hline $\begin{array}{l}\text { Quality of Human } \\
\text { Resources }\end{array}$ & 0,130 & 4 & 0,520 & 3 & 0,390 & 3 & 0,390 & 3 & 0,390 \\
\hline $\begin{array}{l}\text { Good Cooperation } \\
\text { between workers }\end{array}$ & 0,087 & 3 & 0,261 & 3 & 0,261 & 2 & 0,174 & 2 & 0,174 \\
\hline $\begin{array}{l}\text { Government regulations } \\
\text { and permits }\end{array}$ & 0,087 & 3 & 0,261 & 1 & 0,087 & 3 & 0,261 & 1 & 0,087 \\
\hline $\begin{array}{l}\text { Product name and brand } \\
\text { image }\end{array}$ & 0,130 & 4 & 0,520 & 4 & 0,520 & 2 & 0,260 & 2 & 0,260 \\
\hline $\begin{array}{l}\text { Product quality and } \\
\text { variety }\end{array}$ & 0,130 & 4 & 0,520 & 3 & 0,390 & 4 & 0,520 & 2 & 0,260 \\
\hline $\begin{array}{l}\text { Availability Human } \\
\text { Resources }\end{array}$ & 0,130 & 3 & 0,390 & 3 & 0,390 & 4 & 0,520 & 3 & 0,390 \\
\hline Supporting work facilities & 0,087 & 2 & 0,174 & 3 & 0,261 & 3 & 0,261 & 4 & 0,348 \\
\hline Good research facilities & 0,087 & 1 & 0,087 & 1 & 0,087 & 4 & 0,348 & 3 & 0,261 \\
\hline $\begin{array}{l}\text { Ability to use information } \\
\text { technology (internet) in } \\
\text { good promotion }\end{array}$ & 0,130 & 4 & 0,520 & 4 & 0,520 & 1 & 0,130 & 1 & 0,130 \\
\hline
\end{tabular}

\section{1,000}

\begin{tabular}{|c|c|c|c|c|c|c|c|c|c|}
\hline External Factor & & & & & & & & & \\
\hline Customer requirement & 0,188 & 2 & 0,376 & 3 & 0,564 & 3 & 0,564 & 3 & 0,564 \\
\hline $\begin{array}{l}\text { Broad market } \\
\text { segmentation }\end{array}$ & 0,125 & 3 & 0,375 & 3 & 0,375 & 3 & 0,375 & 2 & 0,25 \\
\hline There is a retail market & 0,188 & 2 & 0,376 & 4 & 0,752 & 3 & 0,564 & 2 & 0,376 \\
\hline Positive market reaction & 0,125 & 3 & 0,375 & 2 & 0,25 & 2 & 0,25 & 1 & 0,125 \\
\hline $\begin{array}{l}\text { Increasing number of } \\
\text { competitor's products }\end{array}$ & 0,188 & 3 & 0,564 & 3 & 0,564 & 2 & 0,376 & 2 & 0,376 \\
\hline $\begin{array}{l}\text { Increase in similar } \\
\text { imported products }\end{array}$ & 0,188 & 2 & 0,376 & 2 & 0,376 & 3 & 0,564 & 1 & 0,188 \\
\hline Total & 1,000 & & 5,695 & & 5,787 & & 5,557 & & 4,179 \\
\hline
\end{tabular}

From the QSPM Matrix on tabel 3, the results obtained are alternative strategies that are prioritized by the company with the highest total TAS. The following is a ranking table of the company's prioritized alternative strategies. 
International Journal of Engineering Research and Advanced Technology, Vol. 8, No2, February -2022

Table 4 Total TAS

\begin{tabular}{clcc}
\hline No. & \multicolumn{1}{c}{ Alternative Strategy } & Total TAS & Rank \\
\hline 1. & $\begin{array}{l}\text { Utilizing information technology } \\
\text { (internet) for marketing }\end{array}$ & 5,787 & 1 \\
\hline 2. & $\begin{array}{l}\text { Strengthening product and company } \\
\text { brand image }\end{array}$ & 5,695 & 2 \\
\hline 3. & Create new product variations & 5,557 & 3 \\
\hline 4. & Improve work facilities & 4,179 & 4 \\
\hline
\end{tabular}

Table 4 shows the alternative strategy with the highest total TAS of 5,787 is to use information technology (internet) for marketing. Followed by the second rank with a total of 5,695 TAS, namely strengthening the brand image of products and companies. Ranked third with a total TAS of 5,557 which is making new product variations and ranked fourth with a total of TAS 4,179 which is improving work facilities.

\subsection{Blue Ocean}

The Blue Ocean Strategy approach used here acts as a basis for making decisions on the application of the right strategy to the results of the analysis of the Quantitative Strategic Planning Matrix (QSPM). The steps used are the Four Actions Framework, namely determining the factors to be eliminated, increased, reduced, and created. The use of these steps is considered suitable to be an alternative decision making found from the previous QSPM analysis.

\section{1) Eliminating Factors}

One of the strength factors of PT. Budi Andhika Prima Ayudia is having a wide variety of products with various sizes. However, this will be an advantage if the quantity of products purchased by customers in each variant is in demand or has a high level of demand. But in reality, there are some products that are less desirable so that customers rarely buy or repeat orders are small. For this reason, it is necessary to eliminate product variations that are rarely purchased or are less attractive to customers so that companies can focus more on increasing product innovation based on products of interest.

\section{2) Reduced Factors (Reduce)}

Eliminating product variants that are rarely purchased, of course this will be sustainable by reducing the supply of raw materials needed to make products that consumers rarely buy. This is intended so that there are not too many raw materials stored in the warehouse which can cause several possible losses, including increased raw material maintenance costs if they are not used too often.

\section{3) Enhanced Factor (Raise)}

Increasing product sales, PT. Budi Andhika Prima Ayudia needs improvement in the use of information technology, especially the internet. The way to increase the use of good internet technology is to display sufficient, easily accessible, and attractive information to make potential customers interested in the products offered. In increasing the use of internet technology, companies must have a commitment to continuously update the appearance of pages both on the website, e-commerce, and social media and are always ready to serve customers quickly (fast response). In addition, factors that must be improved are research facilities. This is useful to be able to continue to develop products and follow current trends.

4) Factors that are created (Create)

In order to support in increasing the use of internet technology, PT. Budi Andhika Prima Ayudia needs to prepare information system experts. Recruiting experts in the field of information systems, especially websites, e-commerce, and corporate social media, will make the product promotion system more well-maintained, and the company will have a greater opportunity to increase product sales. Apart from that, the company can also make product packaging design updates to make it more attractive. Creating reverse logistics for cosmetic products which include B2C commercial returns, warranty returns, and so on. Innovation also needs to be done on the products made by the company, one of which is making new products with an even better composition of raw materials. 
International Journal of Engineering Research and Advanced Technology, Vol. 8, No2, February -2022

\subsection{Eliminate-Reduce-Raise-Create (ERRC) Scheme}

Based on the analysis of the Four Actions Framework, the next step is to create an ERRC scheme and act according to the results of the framework. Here is the ERRC Scheme.

Table 5. ERRC Scheme

\begin{tabular}{|c|c|}
\hline $\begin{array}{l}\text { Eliminate } \\
\text { - } \quad \text { Product variations that are slow } \\
\text { moving or less attractive to consumers }\end{array}$ & $\begin{array}{l}\frac{\text { Reduce }}{\text { - Inventory of raw materials for products }} \\
\text { that consumers rarely buy }\end{array}$ \\
\hline $\begin{array}{l}\text { Raise } \\
\text { - } \\
\text { - } \quad \text { Utilization of information technology } \\
\text { (internet) } \\
\text { - } \quad \text { Updating the latest promotional tools } \\
\text { Improved product photo quality to } \\
\text { make it more attractive }\end{array}$ & \begin{tabular}{ll} 
& \multicolumn{1}{c}{ Create } \\
- & New more attractive Packaging Design \\
- & - Reverse Logistics of cosmetic products \\
- & - New perts for internet marketing \\
composition of raw materials
\end{tabular} \\
\hline
\end{tabular}

\section{CONCLUSION}

Based on the results and discussions that have been carried out, it can be concluded that the formulation of a strategy with a blue ocean strategy approach is to innovate value by creating new things that have never been planned by the company, as well as creating product or process innovations that are not widely practiced by the industry. similar cosmetics. PT. Budi Andhika Prima Ayudia has a focus on quite a lot of raise and create schemes compared to eliminate and reduce, this of course needs serious attention if the company wants to have a big enough opportunity to reach a better and wider market.

\section{REFERENCES}

1. Alam, S., \& Islam, M. T. (2017). Impact of blue ocean strategy on organizational performance: A literature review toward implementation logic. IOSR Journal of Business and Management, Vol. 19, No. 1

2. Amrina, U., \& Adriyani, O. (2020) Analysis of Lean and Green Drivers for Sustainable Cosmetics SMIs Using Interpretive Structural Modeling (ISM). International Journal of Engineering Research and Advance Technology (IJERAT) Vol. 6, No. 5.

3. Assauri, Sofyan 2004. Marketing Management: Fundamentals, Concepts and Strategies. PT. Jakarta: Grafindopersada.

4. Chrisnathaniel, H. C., Wilopo., M. Kholid Mawardi (2017). Business Analysis Using a Bluet Ocean Strategy Approach in Creating New International-Scale Market Spaces (Case Study at Pt Kebon Agung) Journal of Business Administration (Jab)|Vol. 43 No.1

5. David, Fred R, 2006, Strategic Management, Ten Edition, Salemba Empat, Jakarta Davis, Keith and Newstrom, 2014, Behavior in Organizations, Seventh Edition, Publishers. Erlangga, Jakarta.

6. Ministry of Industry. (2018). The national cosmetic industry grew by 20\%. Accessed on February 22019 , from the Ministry of Industry of the Republic of Indonesia Website

7. Kim, W.C., Mauborgne, R. (2005), Value Innovation: a leap into the blue ocean, Journal of Business Strategy, Vol. 26, No. 4, pp. 22-28.

8. Kim, W. C., \& Mauborgne, R. (2014). Blue ocean strategy, expanded edition: How to create uncontested market space and make the competition irrelevant: Harvard business review Press.

9. Kumadji, R.S., \& Yulianto, E. (2016). IMPLEMENTATION OF BLUE OCEAN STRATEGY (BOS) IN AN EFFORT TO INCREASE COMPETITIVE ADVANTAGE (Study on Waroeng Steak And Shake Branch Jl. Kawi Bawah 18 Malang). Journal of Business Administration, Vol. 30, No. 1, 103-108.

10. Jogiyanto. (2008). Portfolio Theory and Investment Analysis. Fifth Edition, BPFE. Yogyakarta.

11. Nugraha, T. W., \& Priminingtyas, D. N. (2016). Cemara Soy Sauce Business Development Strategy Using Blue Ocean Strategy and Balanced Scorecard Methods at Cemara Food SMEs, Talun District, Blitar Regency. HABITAT, Vol. 27, No. 1, 14-24.

12. Parlinda, Wahyudin.(2014). Influence of Leadership, Training Motivation, and Work Environment on Employee Performance. Postgraduate Program at Muhammadiyah University of Surakarta

13. Puspitasari, D., \& Novasari, L. (2019). Business Development Through the Implementation of Blue Ocean Strategy in SME Batik Zie Semarang. ACCURATE Journal of Scientific Accounting FE UNIBBA, Vol. 10, No. 3, 31-40.

15. Purba, H.H. (2009). Customer Value Innovation in Product Planning \& Development: Blue Ocean Strategy Application in Achieving Excellence, First Edition, Yogyakarta: Graha Ilmu Publisher 
16. Rezeki, S., Sentanu, I. G. E. P. S., Sanawiri, B., Shankar, K., \& Thanh, P. (2019). Blue Ocean Strategy for creating Value of the Organization: Examination of Differentiation with Red Ocean Strategy., International Journal of Recent Technology and Engineering, Vol. 8, No. 2S11

17. Sarkis, Joseph, (2003). Quantitative Models for Performance Measurement Systems Alternate Considerations (Quantitative Strategic Planning Matrix/QSPM). International Journal of Production Economics. Vol. 86, (1), 81-90

18. Setijono, D. 2008. Value Innovation and A Cognitive Map of Stakeholder-oriented Quality Management, 11th QMOD Conference. Quality Management and Organizational Development Attaining Sustainability From Organizational Excellence to Sustainable Excellence, 20-22 August, 2008 in Helsingborg, Sweden

19. Susanto, A. K. (2015) Analysis of Value Innovation at PT. Wijaya Panca Sentosa Food through the Blue Ocean Strategy. Agora, Student Journal of Business Management Vol. 3, No. 1.

20. Sutanto, Y., M. Suyanto., Hanif Al Fatta. (2013) Analysis of Value Innovation as Corporate Strategy Design at Stmik Amikom Yogyakarta, Journal of Information Technology Vol. VII Number 22 March 2013.

21. Tambrin, M., 2010. The Effect of Brand Image on Simpati Card Customers on Student Satisfaction at Trunojoyo University, Madura. Journal of Management Studies. Vol 4 No.1 April 2010 